\title{
Risk Factors for Obstructive Sleep Apnea and the Association of Obstructive Sleep Apnea with Daytime Sleepiness, Obesity and Comorbidity
}

\author{
Obstrüktif Uyku Apnesinde Risk Faktörleri, Obstrüktif Uyku Apnesi ile Gündüz \\ Uykululuğu, Obezite ve Komorbidite IIlișkisi
}

\author{
(D) Ersin Ersoy, (1) Yeliz Mercan* \\ Kırklareli University Health Sciences Institute, Department of Public Health, Kırklareli, Turkey \\ *Kırklareli University Faculty of Health, Department of Health Management, Kırklareli, Turkey
}

\begin{abstract}
Objective: The purpose of the study was to identify the factors that affect Obstructive Sleep Apnea Syndrome (OSAS) in adults and determine the association between obstructive sleep apnea and daytime sleepiness, obesity and comorbidity.

Materials and Methods: This retrospective study was conducted in Çanakkale from July 2017-June 2018 with 682 adults ( $\geq 18$ yr). An Apnea-hypopnea index (AHI) score $\geq 5$ obtained from polysomnography measurement was considered as OSAS. The Epworth Sleepiness Scale (ESS) was used to identify excessive daytime sleepiness (EDS).

Results: A total of $22.1 \%$ of adults had mild, $15.8 \%$ moderate and $36.5 \%$ severe OSAS. According to multivariate logistic regression analysis, high OSAS risk was associated with men of age greater than 50 years, who were alcohol users, EDS, overweight or obese and had at least two comorbidities $(p<0.05)$. OSAS risk was higher in patients with hypertension and chronic obstructive pulmonary disease (COPD) $(p<0.05)$. According to adjusted multivariate linear regression analysis, with each 1-unit increase in ESS score $[\beta: 0.416,95 \%$ confidence interval (Cl): 0.124, 0.708], Body Mass index (BMI) $(\beta: 1.701,95 \% \mathrm{Cl}$ : $1.390,2.011)$ and comorbidity ( $\beta: 2.441,95 \% \mathrm{Cl}: 0.121,4.762), \mathrm{AHI}$ increased significantly.

Conclusion: Approximately three out of every four participants had OSAS. Male gender, advanced age, alcohol use, EDS, obesity and the presence of comorbidities increased the risk of OSAS. The risk was higher with hypertension or COPD. AHI increased as the ESS score, BMI and number of comorbidities increased. Healthcare professionals should identify those at risk when detecting undiagnosed OSAS cases and refer them to appropriate clinics for early diagnosis and intervention.

Keywords: Obstructive sleep apnea, Apnea-hypopnea index, sleepiness, excessive daytimes sleepiness, obesity Body Mass index, comorbidity
\end{abstract}

Öz

Amaç: Araştırmada yetişkinlerde Obstrüktif Uyku Apne Sendromunu (OSAS) etkileyen faktörleri saptamak ve OSAS ile gündüz uykululuğu, obezite ve komorbidite sayısı arasındaki ilişkiyi belirlemek amaçlandı. Gereç ve Yöntem: Bu retrospektif araştırma Çanakkale'de Temmuz 2017-Haziran 2018 tarihleri arasında 18 yaş ve üstü 682 yetişkin ile yürütüldü. Polisomnografi ölçümünden elde edilen Apne-hipopne indeksi $(\mathrm{AHI}) \geq 5$ ise OSAS olarak değerlendirildi. Gündüz uykululuğunu belirlemede Epworth Uykululuk Ölçeği (EUÖ) kullanıldı.

Bulgular: Katılımcıların \%22,1'i hafif, \%15,8'i orta, \%36,5'i şiddetli düzeyde OSAS'lidir. Multivariate lojistik regresyon analizine göre: OSAS riski erkeklerde, 50 yaş ve üzerinde, alkol kullananlarda, gündüz uykululuğu olanlarda, fazla kilolu ve obezlerde, iki ve daha fazla hastalığ olanlarda yüksektir $(p<0,05)$. Hipertansiyon ve kronik obstrüktif akciğer hastalığı (KOAH) hastalarında OSAS riski daha yüksektir $(p<0,05)$. Düzeltilmiş multivariate lineer regresion analizine göre; EUÖ skorunun [ $\beta: 0,416, \% 95$ güven aralığı (GA): 0,124-0,708)], Vücut Kütle indeksinin (VKI) $(\beta: 1,701, \% 95$ GA: 1,390-2,011) ve komorbiditenin $(\beta: 2,441$, \%95 GA: 0,121-4,762) her 1-birim artışında AHI artmaktadır $(p<0,05)$. Sonuç: Yaklaşık her dört katılımcıdan üçü OSAS'lidir. Erkek cinsiyet, ileri yaş, alkol kullanma, aşırı gündüz uykululuğu, fazla kilo ve obezite, komorbidite OSAS riskini artırmaktadır. Hipertansiyon ve KOAH hastalarında risk daha yüksektir. EUÖ skoru, VKi ve komorbidite artııç̧a AHI artmaktadır. Sağlık çalışanları tanı konmamış OSAS olgularının tespitinde risk altında olanları saptamalı, erken tanı ve girişim için ilgili kliniklere yönlendirmelidir.

Anahtar Kelimeler: Obstrüktif uyku apnesi, Apne-hipopne indeksi, uykululuk, aşırı gündüz uykululuğu, obezite, Vücut Kütle indeksi, komorbidite, yetişkin 


\section{Introduction}

Obstructive Sleep Apnea syndrome (OSAS) is among the most frequent sleep-related respiratory disorders (1). Collapse or obstruction of the pharyngeal airway during sleep is characteristic of OSAS, which results in partial or complete airflow restriction in nose and mouth (2). The prevalence of OSAS, which is reported between $9 \%$ and $38 \%$ in general population (3), varies between $61 \%$ and $88 \%$ in those referring to sleep units [Apnea-hypopnea index (AHI) $\geq 5.0$ events/h] (4-6). Advanced age, male gender, smoking, alcohol use, obesity, metabolic and chronic conditions play important roles in OSAS $(3,7,8)$.

Obesity is one of the main risk factors for OSAS development. It has been reported in previous studies that anthropometric measurements like Body Mass index (BMI), waist circumference and neck circumference were high in patients with OSAS, and metabolic conditions were decisive for OSAS $(5,8,9)$. In a previous study, it was found that one-third of obese patients were in the high-risk OSAS group, and two-thirds of highrisk patients with OSAS had hypertension (10). It was shown that among the comorbid diseases, cardiovascular diseases, respiratory diseases, and diabetes mellitus (DM) increased the risk of OSAS (11-14). OSAS appears as a potential trigger for worse prognosis by deteriorating chronic organ damage, affecting the course and severity of diseases, and by adversely affecting the quality of life $(7,15)$. The hypoventilation and/ or oxygen desaturation, which are frequently seen in OSAS, lead to sleep disorders $(16,17)$. Among these, EDS is a very common symptom for patients with OSAS, and is observed in $12 \%$ to $65 \%$ of patients (18). EDS can also result in increases in morbidity and mortality rates, and can cause traffic and work accidents $(19,20)$.

Polysomnography (PSG), which is considered the gold standard for OSAS diagnosis, is not used as a screening test due to high costs and limited availability. For this reason, PSG is more important for patients who have higher risks and comorbid conditions in diagnosing OSAS (21). OSAS, which leads to an increase in chronic disease burden and direct or indirect health expenditures, remains as a major public health problem $(10,18)$. The purpose of the present study was to determine the factors that affect OSAS in adults, and determine the association between obstructive sleep apnea and daytime sleepiness, obesity and comorbidity.

\section{Materials and Methods}

\section{Study design}

This retrospective research, whose medical records were accessed between 01.11.2018 and 15.12.2018, was conducted in Çanakkale. A total of 758 people, who applied to the Sleep Apnea Unit of Ezine State Hospital and who underwent PSG examination for at least 6 hours between July 1, 2017, and June 30,2018 , were included in the study. A total of 76 people whose PSG process could not be completed due to inadequate sleep or quitting the process $(n=53)$, whose archive data could not be found ( $n=21)$, who were below the age of $18(n=2)$ were excluded from the study, and the records of 682 adults who were over the age of 18 were examined.

\section{OSAS assessment}

The Grael 4K (Compumedics, Victoria, Australia) PSG Device was used in the study. The polysomnographic screening was carried out by using the standard technique. PSG was carried out in line with the American Academy of Sleep Medicine criteria (22). The definition of apnea was defined as decreased airflow at least $90 \%$ with minimum $10 \mathrm{~s}$, and the definition of hypopnea was made as decreased airflow at least $30 \%$ with minimum $3 \%$ desaturation in preceding $30 \mathrm{~s}$, and decrease in chest-wall movement and/or arousal. AHI was defined as the mean number of apneas and hypopneas per hour during sleep, and OSAS was defined as AHI with a minimum of 5.0 events $/ \mathrm{h}$. OSAS severity was defined as mild $(5.0 \leq \mathrm{AHI}<15.0$ events $/ \mathrm{h})$, moderate $(15.0 \leq \mathrm{AHI}<30.0$ events/h), or severe $(\mathrm{AHI} \geq 30.0$ events/h).

\section{Variables of the study}

The dependent variable of the research was the OSAS entity. $\mathrm{AHI} \geq 5.0$ events/h were evaluated as OSAS. Gender, age, level of education, working status, smoking and alcohol use, daily sleep duration, Ehlers-Danlos syndrome (EDS), BMI, and comorbidity status were used as independent variables in the study. The study described daily sleep time as the sleep time between the average sleep and wake-up times of a person in the past week. The American National Sleep Foundation has recommended 7-9 hours for adults aged 18-64, and 7-8 hours for adults aged 65 and over (23). In this study, 7-9 hours of sleep was considered as adequate, less than 7 hours of sleep inadequate, and more than 9 hours of sleep was considered as excess. Daytime was evaluated according to sleepiness, ESS. The scores from the scale of Appleton et al. (15) vary between 0-24, with high scores showing daytime sleepiness (24); and 11 points and over according to cut-off-point refer to EDS and circadian rhythm change. BMI was calculated with the formula of body weight/height ${ }^{2}\left(\mathrm{~kg} / \mathrm{m}^{2}\right)$. According to World Health Organization classification, BMI was evaluated as less than $18.50 \mathrm{~kg} / \mathrm{m}^{2}$ underweight, $18.50-24.99 \mathrm{~kg} / \mathrm{m}^{2}$ normal, 25.0-29.9 kg/m² overweight, $30.00 \mathrm{~kg} / \mathrm{m}^{2}$ and more obese. Minimum one disease that was diagnosed by a physician, lasting two years, and requiring continuous medication was considered as a chronic disease (cardiovascular, respiratory, endocrine, neurological, psychiatric, genitourinary, gastrointestinal, and metabolic). In addition to OSAS, the presence of at least one chronic disease was defined as comorbidity according to the data which were obtained from chronic disease data records of the patients.

\section{Data analysis}

Descriptive statistics were used for data analysis, and Pearson chi-square test was used to compare the rates in independent groups. Further analysis of OSAS and categorical variables were identified by using multivariate logistic regression analyses (enter strategy). Dummy variables were created in more than 
two-category variables modeled, according to which the age was defined as 50 years less, education level as secondary school or higher, daily sleep time as 7-9 hours, BMI as $25.0 \mathrm{~kg} / \mathrm{m}^{2}$ less, and the number of comorbid diseases as none reference group. The explanatory power of the model was evaluated according to Nagelkerke R-square (Nagelkerke $\mathrm{R}^{2}$ ). In univariate analysis, variables with $p<0.10$ were taken in the model. Multivariate linear regression analysis (enter strategy) was used to analyze the relationship between $\mathrm{AHI}$ score and Epworth Sleepiness scale (ESS), BMI and the number of comorbidities. The model's confounding variables were identified as age, gender, smoking, and use of alcohol. The explanatory status of the models was evaluated by Adjusted R-square (Adj. $R^{2}$ ). A two-tailed $p<0.05$ was considered a statistically significant level.

\section{Statistical Analysis}

The analysis was performed using the Statistical Package for the Social Sciences, version 22.0 (SPSS Inc., Chicago, IL, USA).

\section{Results}

In Table 1, the descriptive characteristics of participants are shown. The mean age was 50.02 \pm 12.79 (range: 18-89), and $68.6 \%$ of the adults were male. A total of $41.5 \%$ of the respondents were primary school and lower graduates, $38.1 \%$ smoked, and $22.7 \%$ used alcohol. A total of $31.4 \%$ of the adults had insufficient daily sleep times or more $(\leq 6$ or $\geq 10$ hours), $48.1 \%$ had EDS, $61.9 \%$ were obese, $51.8 \%$ had at least one comorbid disease, and the most frequently diagnosed comorbidity was hypertension (33.0\%). A total of $74.5 \%$ of the participants were diagnosed with OSAS, $22.1 \%$ of them had mild, $15.8 \%$ moderate, and $36.5 \%$ had severe OSAS.

The relation between OSAS according to some characteristics of the adults is illustrated in Table 2 and Table 3 by multivariate logistic regression analysis (enter strategy). In the models created, $26.8 \%$ and $8.6 \%$ of the variance in OSAS according to Nagelkerke were explained, respectively $(p<0.001)$. In the study, OSAS risk was significantly higher in the male gender $(p<0.001)$, in 50 and over years old $(p=0.001)$, in alcohol users $(p=0.001)$, in people with EDS $(\geq 11)(p=0.026)$, overweight $(p=0.012)$ and obese $(p<0.001)$, and in patients with at least two comorbidities $(p=0.005)$ (Table 2$)$. A higher risk of OSAS was detected in the presence of hypertension $(p<0.001)$ and chronic obstructive pulmonary disease (COPD) $(p=0.045)$ among comorbid diseases (Table 3).

The relationship between adults' $\mathrm{AHI}$ scores and ESS, BMI and the number of comorbidities is illustrated with the multivariate linear regression analysis in Table 4 . A total of $21.2 \%$ of the $A H I$ variance $\left(\operatorname{adj} . R^{2}\right)$ was explained $(p<0.001)$ in the model that was corrected according to the gender, age, smoking and alcohol use of participants. In this respect, with each 1-unit increase in ESS score, there was a 0.416-unit increase in $\mathrm{AHI}$ $[\beta, 95 \%$ confidence interval $(\mathrm{Cl}): 0.124$ to $0.708, \mathrm{p}=0.005]$; with each 1-unit increase in $\mathrm{BMI}$, there was a 1.701-unit increase in $\mathrm{AHI}(\beta, 95 \% \mathrm{Cl}: 1.390$ to $2011, \mathrm{p}<0.001)$; with each 1 -comorbid disease, there was a 2.441-unit increase in $\mathrm{AHI}(\beta$, 95\% Cl: 0.121 to $4.762, \mathrm{p}=0.039$ ).

\begin{tabular}{|c|c|c|}
\hline Variables & $\mathbf{n}$ & $\%$ \\
\hline \multicolumn{3}{|l|}{ Gender } \\
\hline Female & 214 & 31.4 \\
\hline Male & 468 & 68.6 \\
\hline Age (year) & \multicolumn{2}{|c|}{ Mean \pm SD: $50.02 \pm 12.79$ range: $18-89$} \\
\hline$<40$ & 138 & 20.2 \\
\hline $40-64$ & 456 & 66.9 \\
\hline$\geq 65$ & 88 & 12.9 \\
\hline \multicolumn{3}{|l|}{ Education level } \\
\hline Graduate or higher & 155 & 22.7 \\
\hline High school & 120 & 17.6 \\
\hline Secondary school & 124 & 18.2 \\
\hline Primary school or lower & 283 & 41.5 \\
\hline \multicolumn{3}{|l|}{ Smoking } \\
\hline No & 422 & 61.9 \\
\hline Yes & 260 & 38.1 \\
\hline \multicolumn{3}{|l|}{ Use of alcohol } \\
\hline No & 527 & 77.3 \\
\hline Yes & 155 & 22.7 \\
\hline $\begin{array}{l}\text { Daily sleep duration } \\
\text { (hours) }\end{array}$ & \multicolumn{2}{|c|}{ Mean \pm SD: $7.63 \pm 1.57$ range: $1.5-15.0$} \\
\hline $7-9$ & 468 & 68.6 \\
\hline$\leq 6$ or $\geq 10$ & 214 & 31.4 \\
\hline EDS & \multicolumn{2}{|c|}{ Mean \pm SD: $10.78 \pm 6.68$ range: $0-24$} \\
\hline$<11$ & 354 & 51.9 \\
\hline$\geq 11$ & 328 & 48.1 \\
\hline \multicolumn{3}{|l|}{ BMI } \\
\hline Normal \& underweight & 73 & 10.7 \\
\hline Overweight & 187 & 27.4 \\
\hline Obese & 422 & 61.9 \\
\hline \multicolumn{3}{|c|}{ The number of comorbidities } \\
\hline 0 & 329 & 48.2 \\
\hline 1 & 202 & 29.6 \\
\hline$\geq 2$ & 151 & 22.2 \\
\hline \multicolumn{3}{|l|}{ Comorbid diseases* (yes) } \\
\hline Hypertension & 225 & 33.0 \\
\hline Diabetes mellitus & 116 & 17.0 \\
\hline Coronary heart failure & 61 & 8.9 \\
\hline COPD & 32 & 4.7 \\
\hline Asthma & 57 & 8.4 \\
\hline Depression & 34 & 5.0 \\
\hline Thyroid diseases & 24 & 3.5 \\
\hline Chronic renal failure & 5 & 0.7 \\
\hline AHI (events/hour) & \multicolumn{2}{|c|}{$\begin{array}{l}\text { Mean } \pm \text { SD: } 28.09 \pm 28.85 \text { range: } \\
0.0-138.2\end{array}$} \\
\hline$<5$ & 174 & 25.5 \\
\hline $5.0 \leq \mathrm{AHI}<15.0$ & 151 & 22.1 \\
\hline $15.0 \leq \mathrm{AHI}<30.0$ & 108 & 15.8 \\
\hline $\mathrm{AHI} \geq 30.0$ & 249 & 36.5 \\
\hline \multicolumn{3}{|c|}{$\begin{array}{l}\text { *Multiple options are marked, SD: Standard deviation, BMI: Body Mass index, } \\
\text { AHI: Apnea-hypopnea index, COPD: Chronic obstructive pulmonary disease, } \\
\text { EDS: Ehlers-Danlos syndrome }\end{array}$} \\
\hline
\end{tabular}


Ersoy and Mercan.

Obstructive Sleep Apnea and Related Factors

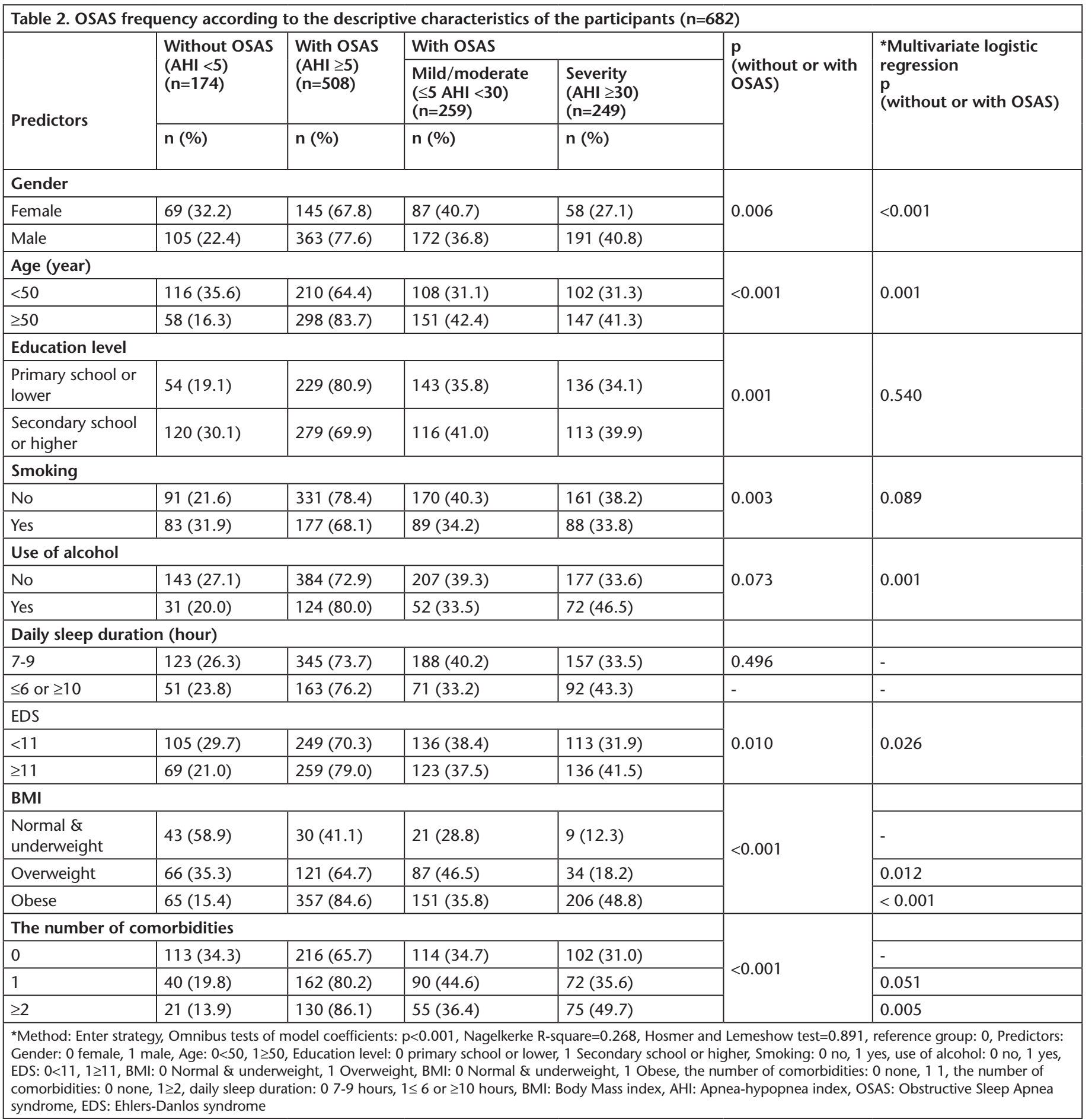

\section{Discussion}

In our present day, considering the increase in the elderly population and in the number of people who are obese, and the high comorbidity burden, OSAS has a great effect on public health. Approximately three out of every four people were diagnosed with OSAS in the study. It was found that this finding was consistent with previous studies showing high
OSAS prevalence in adults referring to the sleep units $(4,5,7)$ or high AHI averages in individuals with OSAS $(6,10,19)$.

It was reported in previous studies that increased OSAS frequency with advanced age stemmed from the changes in body fat distribution, plasma adipocytes, neural control of the upper airway muscles or changes in anthropometric measurements like neck and waist circumference, and comorbidities increased the predisposition to OSAS $(3,25,26)$. It was also reported that 


\begin{tabular}{|c|c|c|c|c|c|c|}
\hline \multirow{3}{*}{ Predictors } & \multirow{3}{*}{$\begin{array}{l}\text { Without OSAS } \\
(\mathrm{AHI}<5) \\
(\mathrm{n}=174) \\
\mathrm{n}(\%)\end{array}$} & \multirow{3}{*}{ 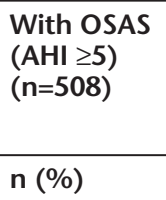 } & \multicolumn{2}{|l|}{ With OSAS } & \multirow{3}{*}{$\begin{array}{l}\text { p } \\
\text { (without or } \\
\text { with OSAS) }\end{array}$} & \multirow{3}{*}{$\begin{array}{l}\text { *Multivariate } \\
\text { logistic regression } \\
p \\
\text { (without or with } \\
\text { OSAS) }\end{array}$} \\
\hline & & & $\begin{array}{l}\text { Mild/moderate } \\
(\leq 5 \mathrm{AHI}<30) \\
(\mathrm{n}=259)\end{array}$ & \begin{tabular}{|l|} 
Severity \\
$(\mathrm{AHI} \geq 30)$ \\
$(\mathrm{n}=249)$ \\
\end{tabular} & & \\
\hline & & & n (\%) & n (\%) & & \\
\hline \multicolumn{7}{|c|}{ Hypertension } \\
\hline No & $145(31.7)$ & $312(68.3)$ & $170(37.2)$ & $142(31.1)$ & $<0.001$ & $<0.001$ \\
\hline Yes & $29(12.9)$ & $196(87.1)$ & $89(39.6)$ & $107(47.6)$ & - & \\
\hline \multicolumn{7}{|l|}{ DM } \\
\hline No & $156(27.6)$ & $410(72.4)$ & $225(39.8)$ & $185(32.7)$ & 0.007 & 0.479 \\
\hline Yes & $18(15.5)$ & $98(84.5)$ & $34(29.3)$ & $64(55.2)$ & - & \\
\hline \multicolumn{7}{|c|}{ Coronary heart failure } \\
\hline No & $166(26.7)$ & $455(73.3)$ & $231(37.2)$ & $224(36.1)$ & 0.020 & 0.169 \\
\hline Yes & $8(13.1)$ & $53(86.9)$ & $28(45.9)$ & $25(41.0)$ & - & \\
\hline \multicolumn{7}{|l|}{ COPD } \\
\hline No & $172(126.5)$ & $478(73.5)$ & $245(37.7)$ & $233(35.8)$ & 0.010 & 0.045 \\
\hline Yes & $2(6.3)$ & $30(93.8)$ & $14(43.8)$ & $16(50.0)$ & - & \\
\hline \multicolumn{7}{|l|}{ Asthma } \\
\hline No & $161(25.8)$ & $464(74.2)$ & $234(37.4)$ & $230(36.8)$ & 0.624 & - \\
\hline Yes & $13(22.8)$ & $44(77.2)$ & $25(43.9)$ & $19(33.3)$ & - & - \\
\hline \multicolumn{7}{|l|}{ Depression } \\
\hline No & $165(25.5)$ & $483(74.5)$ & $244(37.7)$ & $239(36.9)$ & 0.895 & - \\
\hline Yes & $9(26.5)$ & $25(73.5)$ & $15(44.1)$ & $10(29.4)$ & - & - \\
\hline \multicolumn{7}{|c|}{ Thyroid diseases } \\
\hline No & $167(25.4)$ & $491(74.6)$ & $247(37.5)$ & $244(37.1)$ & 0.676 & - \\
\hline Yes & $7(29.2)$ & $17(70.8)$ & $12(50.0)$ & $5(20.8)$ & - & - \\
\hline \multicolumn{7}{|c|}{ Chronic renal failure } \\
\hline No & $174(25.7)$ & $503(74.3)$ & $257(38.0)$ & $246(36.0)$ & NA & - \\
\hline Yes & $0(0.0)$ & $5(100.0)$ & $2(40.0)$ & $3(60.0)$ & - & - \\
\hline
\end{tabular}

\begin{tabular}{l}
$\begin{array}{l}\text { Table 4. Multivariate linear regression analysis of the relationship between the participants' AHI scores with their ESS, BMI, and the number } \\
\text { of comorbidities }\end{array}$ \\
\hline
\end{tabular}

OSAS is observed more in male gender, especially due to the prognostic fat distribution (9). In this study, it was determined that the high frequency of OSAS in advanced ages and in men was in line with the literature $(1,5,13,26)$. It is expected that individuals with high education levels adopt healthier lifestyle behaviors because they have a high awareness of disease risk factors. Similarly, in the study conducted by Sunwoo et al. (21), it was found that those from middle school educational level and below were at high risk of OSAS, while high school graduates were at low risk. Although it was observed in the 
study that there was high OSAS frequency in those with primary school or lower education levels, no significant difference was found in line with some of the studies conducted $(17,27)$. This is because of higher BMI in highly trained people.

Smoking and alcohol, which cause changes in sleep architecture, upper airway neuromuscular function, arousal mechanisms and upper airway inflammation, are risk factors for OSAS, and deteriorate it with comorbid conditions $(13,15,21)$. In a study, it was shown that OSAS patients smoked more; and therefore, OSAS severity increased, and one-unit increase in package year caused $15.3 \%$ increase in AHI score (8). In the study, similar to the literature, OSAS risk was determined to be significantly higher in those who use alcohol; and there was no difference in terms of smoking. In a previous study, it was also showed that there were no relations between OSAS and smoking (10). This result was attributed to the fact that the participants stopped smoking after being diagnosed with OSAS.

EDS, which affects daily activity in patients with OSA, affects job performance and increases the risk of accidents for motor vehicle accidents, reducing job efficiency, is a very common symptom $(18,19)$. Visceral obesity and fatty deposits in the upper airway, which are common in OSAS, cause an increase in night wake-up and sleep disorders because fat deposits in the upper airway cause hypoventilation and/or oxygen desaturation during sleep, causing daytime sleepiness (17). Jung et al. (16) showed that the mean ESS scores increased as the severity of OSAS increased (mild to severe). In our study, it was determined that OSAS frequency was higher at significant levels in those who had EDS $(\geq 11)$ compared to those who did not $(<11)$, and $\mathrm{AHI}$ increased at significant levels as the ESS score increased by 1 -unit. Similarly, these results were found to be consistent with previous studies reporting that there were high mean ESS scores in people with $\operatorname{OSAS}(2,10,19)$, and with studies that reported the frequency of high $\operatorname{EDS}(18,21,27)$.

Obesity, which is considered as a chronic inflammatory condition, is one of the most important risk factors for OSAS $(10,25)$. OSAS is common in obese people because of increased body fat distribution and visceral adiposity, decreased plasma adipocytes, and fattening in upper airway muscles stenosis $(9,25,28)$. In a study conducted in China, it was reported that OSAS was detected in all obese people and nearly in all overweight people, and there was a 2.5-fold increase in $\mathrm{AHI}$ scores in BMI's 1-unit increase (5). In a study conducted in Konya, it was shown that one-unit increase in BMI increased OSAS risk by $20.8 \%$ (8). In a study conducted in Australia, it was found that the risk of possible undiagnosed OSAS in obese was 2.2 times higher, and the risk of diagnosed OSAS was 3.6 times higher (15). Other studies also reported that the vast majority of patients with OSAS were obese, high BMI is a risk factor for diseases, and these patients have multiple co-morbidities $(3,17,21)$. This study also found that $\mathrm{AHI}$ increased in BMI increases, OSAS risk in obese people was high, and the results support the literature data.

Among OSAS risk factors, there are many comorbid diseases such as cardiovascular diseases, hypertension, DM, COPD, and OSAS severity and comorbidity was reported to increase
$(1,12,27,29)$. In a study conducted in Australia, it was found that people with at least two comorbidities had a higher risk of OSAS by 8.8 times, this risk was 2.9 times higher in those with at least one cardiometabolic conditions (heart disease, diabetes, high blood pressure), and was 6.6 times higher in those with at least one mental health condition (depression, anxiety/panic disorder) (15). In a study conducted with people aged between 30 and 94 in the United States, it was found that the risk of OSAS varied from 2.1 to 4.9 in comorbid diseases (11). In a study conducted in Israel, it was found that the risk of OSAS in systemic hypertension, hyperlipidemia, and type 2 DM diseases were approximately 3-fold higher (26). In studies conducted in Rome in Italy and Taiwan, it was showed that there is a strong relation between OSAS and MetS, which was found to be a risk factor for DM, hypertension and heart disease as well as other diseases $(17,30)$. Among the studied conducted in Turkey, a Malatya study found that depression and anxiety scores were higher in patients who had REM-associated OSAS (31). In a study conducted in Ankara, it was reported that metabolic syndrome components clustered in OUAS patients (14).

A positive correlation was reported between systolic blood pressure and diastolic blood pressure and $\mathrm{AHI}$ in China (5). In North Korea, on the other hand, it was shown that hypertension, DM, hyperlipidemia, and anxiety were among high-risk comorbid conditions for OSAS (21). In a study conducted in Turkey, it was reported that the risk of OSAS increased at significant levels as the number of comorbid diseases increased, and this risk was higher at significant levels in patients with COPD (2). In a study conducted in Taiwan, it was found that mortality risk was 11 times higher in patients with comorbidity compared to those without comorbidity, and the higher the comorbidity scores were, the higher the risk of death was. In addition, it was also shown that mortality risk in patients with COPD and DM varied between 1.40 and 1.58 (32). In this study, at least one comorbid disease was diagnosed in half of the participants, and as the number of comorbid diseases increased, the $\mathrm{AHI}$ score increased at significant levels. It is considered that the results support the literature data, which stemmed from the use of drugs in addition to the current situation, or age-related sleep architecture and circadian rhythm changes.

\section{Study Limitations}

Since the present study was conducted with individuals who presented to sleep apnea unit, the study has the problem of generalizing the results to the entire society. In the study, which was conducted in retrospective design, the participants that quit smoking could not be evaluated separately since the smoking variable was obtained from the records. Also, the daily sleep times between sleep-awake hours might have been affected by the memory factor.

\section{Conclusion}

Approximately three out of every four participants had OSAS, and more than one-third were at a severe level. Half of the patients had EDS or at least one comorbid disease, and 
approximately one-third was obese. Male gender, 50 and over years old, alcohol use, EDS ( $\geq 11)$, being overweight, obesity and at least two comorbidities increased the risk of OSAS at significant levels. In the case of hypertension or COPD, the OSAS risk was even higher. AHI increases at significant levels as ESS score, BMI or comorbidity increases independent from gender, age, smoking, and alcohol use status.

Today, in general society, obesity and comorbidity prevalence is high, and sleep disorders are frequent. This is a predictor for high undiagnosed OSAS cases. The awareness of primary healthcare professionals and the society regarding OSAS and risk factors must be increased. Adults must be examined in terms of OSAS when they refer to primary healthcare services, taking protective measures; and the point where the treatment should start must be defined based on possible morbidity profiles of patients. In future studies, OSAS-related comorbidities, and parameters regarding the genetic, physiological, and epidemiological or sleep patterns of OSAS must be defined, and strategies should be developed to facilitate the diagnosis and management of OSAS at primary healthcare services.

\section{Acknowledgements}

This article is based on the master thesis prepared at the Institute of Health Sciences of Kırklareli University. This article was presented as an oral presentation at the $3^{\text {rd }}$ Union of Thrace Universities International Health Sciences Congress held in Çanakkale in Turkey between 24-26 October 2019, and its full text was published in the proceeding book.

\section{Ethics}

Ethics Committee Approval: The study was conducted in line with ethical principles, and was approved by the Ethics Committee of Kırklareli University, Institute of Health Sciences Ethics Committee in 2018 (08/0/2018-P094R00). Permission was obtained from the Republic of Turkey Ministry of Health Çanakkale Provincial Health Directorate for this study, which was carried out retrospectively and whose data were obtained from the records (03/08/2018-18231034-604.02.99).

Informed Consent: It is a retrospective study.

Peer-review: Internally peer-reviewed.

\section{Authorship Contributions}

Concept: E.E., Y.M., Design: E.E., Y.M., Data Collection or Processing: E.E., Y.M., Analysis or Interpretation: E.E., Y.M., Literature Search: E.E., Y.M., Writing: E.E., Y.M.

Conflict of Interest: No conflict of interest was declared by the authors.

Financial Disclosure: The authors declared that this study received no financial support.

\section{References}

1. Venkataraman S, Vungarala S, Covassin N, Somers VK. Sleep apnea, hypertension and the sympathetic nervous system in the adult Population. J Clin Med 2020;9:1-12.

2. Celikhisar H, Dasdemir Ilkhan G. Comparison of clinical and polysomnographic characteristics in young and old patients with obstructive sleep apnea syndrome. Aging Male 2020;1-8.
3. Senaratna CV, Perret JL, Lodge Cl, Lowe AJ, Campbell BE, Matheson MC, Hamilton GS, Dharmage SC. Prevalence of obstructive sleep apnea in the general population: A systematic review. Sleep Med Rev 2017;34:70-81.

4. Abad J, Muñoz-Ferrer A, Cervantes MÁ, Esquinas C, Marin A, Martínez C, Morera J, Ruiz J. Automatic video analysis for obstructive sleep apnea diagnosis. Sleep 2016;39:1507-15.

5. Wang S, Niu X, Zhang P, Su D, Zhang J, Liu W. Analysis of OSAS incidence and influential factors in middle-aged and elderly patients with hypertension. Minerva Med 2019;110:115-20.

6. Sertogullarindan B, Komuroglu AU, Ucler R, Gunbatar H, Sunnetcioglu A, Cokluk E. Betatrophin association with serum triglyceride levels in obstructive sleep apnea patients. Ann Thorac Med 2019;14:63-8.

7. Traaen GM, Øverland B, Aakerøy L, Hunt TE, Bendz C, Sande L, Aakhus S, Zaré H, Steinshamn S, Anfinsen OG, Loennechen JP, Gullestad L, Akre H. Prevalence, risk factors, and type of sleep apnea in patients with paroxysmal atrial fibrillation. Int J Cardiol Heart Vasc 2019;26:100447.

8. Yosunkaya S, Kutlu R, Vatansev H. Effects of smoking on patients with obstructive sleep apnea syndrome. Clin Respir J 2020. doi: 10.1111/ crj.13278. Online ahead of print.

9. Degache F, Sforza E, Dauphinot V, Celle S, Garcin A, Collet P, Pichot V, Barthélémy JC, Roche F, PROOF Study Group. Relation of central fat mass to obstructive sleep apnea in the elderly. Sleep 2013;36:501-7.

10. Singh A, Prasad R, Garg R, Kant S, Hosmane GB, Dubey A, Agarwal A, Verma RK. A study to estimate prevalence and risk factors of Obstructive Sleep Apnea syndrome in a semi-urban Indian population. Monaldi Arch Chest Dis 2017;87:773.

11. Mokhlesi B, Ham SA, Gozal D. The effect of sex and age on the comorbidity burden of OSA: An observational analysis from a large nationwide US health claims database. Eur Respir J 2016;47:1162-9.

12. Bielicki P, Pływaczewski R, Brzóska $K$, Kumor $M$, Barnaś $M$, Jonczak L, Stępkowski TM, Piechuta A, Chazan R, śliwiński P, Kruszewski M. Impact of polymorphism of selected genes on the diagnosis of type 2 diabetes in patients with obstructive sleep apnea. Pol Arch Intern Med 2019;129:6-11.

13. Saraç S, Çetintaş Afşar G. Comorbidity of obstructive sleep apnea syndrome, cronic obstructive lung disease and asthma chronic airway diseases and sleep apnea. J Turk Sleep Med 2017;4:43-7.

14. Yumrukuz Şenel $M$, Bağnu Yüceege $M$, Fırat $H$. The role of the metabolic syndrome criterias to determine moderate to severe sleep apnea patients. J Turk Sleep Med 2020;3:118-23.

15. Appleton SL, Gill TK, Lang CJ, Taylor AW, McEvoy RD, Stocks NP, González-Chica DA, Adams RJ. Prevalence and comorbidity of sleep conditions in Australian adults: 2016 Sleep Health Foundation national survey. Sleep Health 2018;4:13-9.

16. Jung JH, Park JW, Kim DH, Kim ST. The effects of obstructive sleep apnea on risk factors for cardiovascular diseases. Ear Nose Throat J 2019;145561319882548. doi: 10.1177/0145561319882548.

17. Wu WT, Tsai SS, Shih TS, Lin MH, Chou TC, Ting H, Wu TN, Liou $\mathrm{SH}$. The association between obstructive sleep apnea and metabolic markers and lipid profiles. PLoS One 2015;10:e0130279. doi: 10.1371/journal.pone.0130279.

18. Léger D, Stepnowsky C. The economic and societal burden of excessive daytime sleepiness in patients with obstructive sleep apnea. Sleep Med Rev 2020;51:101275.

19. Arita A, Sasanabe R, Hasegawa R, Nomura A, Hori R, Mano M, Konishi N, Shiomi T. Risk factors for automobile accidents caused by falling asleep while driving in obstructive sleep apnea syndrome. Sleep Breath 2015;19:1229-34. 
20. Celikhisar H, Dasdemir Ilkhan G. The association of obstructive sleep apnea syndrome and accident risk in heavy equipment operators. Medicina (Kaunas) 2019;55:599.

21. Sunwoo JS, Hwangbo Y, Kim WJ, Chu MK, Yun $\mathrm{CH}$, Yang KI. Prevalence, sleep characteristics, and comorbidities in a population at high risk for obstructive sleep apnea: A nationwide questionnaire study in South Korea. PLoS One 2018;13:e0193549. doi: 10.1371/ journal.pone.0193549.

22. Berry RB, Budhiraja R, Gottlieb DJ, Gozal D, Iber C, Kapur VK, Marcus CL, Mehra R, Parthasarathy S, Quan SF, Redline S, Strohl KP, Ward SLD, Tangredi MM, American Academy of Sleep Medicine. Rules for scoring respiratory events in sleep: Update of the 2007 AASM manual for the scoring of sleep and associated events. deliberations of the sleep apnea definitions task force of the American Academy of Sleep Medicine. J Clin Sleep Med 2012;8:597-619.

23. Hirshkowitz M, Whiton K, Albert SM, Alessi C, Bruni O, Don Carlos L, Hazen N, Herman J, Katz ES, Kheirandish-Gozal L, Neubauer DN, O'Donnell AE, Ohayon M, Peever J, Rawding R, Sachdeva RC, Setters B, Vitiello M, Ware JC, Hillard PJA. National Sleep Foundation's sleep time duration recommendations: Methodology and results summary. Sleep Health 2015;1:40-3.

24. Agargun MY, Cilli AS, Kara H, Bilici M, Telcioglu M, Semiz UB, Başoğlu C. Validity and reliability of the epworth sleepiness scale. Turk J Psychiatry 1999;10:261-7.

25. Xu T, Lin Y, Sun S, Zhang Q. Changes in four plasma adipokines before and after sleep in OSAS patients. Clin Respir J 2017;11:968-74.
26. Gilat H, Vinker S, Buda I, Soudry E, Shani M, Bachar G. Obstructive sleep apnea and cardiovascular comorbidities: a large epidemiologic study. Medicine (Baltimore) 2014;93:e45. doi: 10.1097/ MD.0000000000000045.

27. Zhou L, Ouyang R, Luo H, Peng Y, Chen P, Ren S, Liu G. Dysfunction of Nrf2-ARE signaling pathway: Potential pathogenesis in the Development of Neurocognitive Impairment in patients with moderate to severe obstructive sleep Apnea-Hypopnea syndrome. Oxid Med Cell Longev 2018;2018:3529709.

28. Zhang DM, Pang XL, Huang R, Gong FY, Zhong X, Xiao Y. Adiponectin, omentin, ghrelin, and visfatin levels in obese patients with severe obstructive sleep apnea. Biomed Res Int 2018;2018:3410135.

29. Bonsignore MR, Baiamonte P, Mazzuca E, Castrogiovanni A, Marrone O. Obstructive sleep apnea and comorbidities: a dangerous liaison. Multidiscip Respir Med 2019;14:8.

30. Angelico F, del Ben M, Augelletti T, de Vita R, Roma R, Violi F, Fabiani M. Obstructive sleep apnoea syndrome and the metabolic syndrome in an internal medicine setting. Eur J Intern Med 2010;21:191-5.

31. Altintop Geckil A, Ermis H. The relationship between anxiety, depression, daytime sleepiness in the REM-related mild OSAS and the NREM-related mild OSAS. Sleep Breath 2020;24:71-5.

32. Chiang CL, Chen YT, Wang KL, Su VY, Wu LA, Perng DW. Comorbidities and risk of mortality in patients with sleep apnea. Ann Med 2017;49:377-83. 